\title{
Is the Federal Reserve Learning? A New Simple Correlation of Inflation and Economic Stability Trends
}

\author{
Romney B. Duffey \\ DSM Associates Inc., Idaho Falls, ID, USA \\ Email: duffeyrb@gmail.com
}

How to cite this paper: Duffey, R.B. (2016) Is the Federal Reserve Learning? A New Simple Correlation of Inflation and Economic Stability Trends. Open Journal of Business and Management, 4, 549-557.

http://dx.doi.org/10.4236/ojbm.2016.44059

Received: July 11, 2016

Accepted: August 14, 2016

Published: August 17, 2016

Copyright $\odot 2016$ by author and Scientific Research Publishing Inc. This work is licensed under the Creative Commons Attribution International License (CC BY 4.0).

http://creativecommons.org/licenses/by/4.0/ (c) (i) Open Access

\begin{abstract}
The relatively recent (last few years) actions by the Federal Reserve and other economic factors have mitigated potential changes in unemployment rate. We examine the trends in economic inflation for the USA using the data and empirical models given in the recent paper by Yellen [1]. A new correlation for the inflation rate trend is developed based on Learning Theory. We may conclude that the Federal Reserve has learnt to control inflation rate via an implicit learning process, and has tempered the fluctuations in unemployment rate, which previously showed evidence of instability. The fluctuations and trends in unemployment do not show evidence of learning, and are fitted by a simple periodic dynamic expression with an underlying unemployment rate of $6.5 \%$. Yellen [1] also discusses the role of "expectation" in forecasting and economic changes in policies and directions. This behavioral response to rule changes is clearly linked to the learning processes in society and by people, which are a fruitful topic for future research on economic predictions and for interpretive purposes.
\end{abstract}

\section{Keywords}

Financial Policy, Inflation, Unemployment, Learning Theory, Correlations, Predictions

\section{The Federal Reserve Inflation Formula}

The Federal Reserve effectively manages interest rates and monetary policy to ensure stable economic growth. In the recent paper by Yellen [1] relationships were shown between inflation, unemployment and wages in elaborating the considerations related to historical trends and future economic performance for the USA. The focus was on the ability to predict both expectations and trends. All the plots and data were given in 
terms of calendar year (or quarters), which is the conventional and easily understood reporting and human timescale used by economists.

Yellen [1] examined the change in the price index for personal consumption expenditures (PCE). The empirical relation for inflation forecasting was given as a running corrected yearly time series, subscript $t$, in annualized growth rates of total and core prices, $\pi_{t}$ and $\pi_{t}^{c}$ respectively, for 1990 to 2014 (all the terms are as defined in [1]):

$$
\pi_{t}=\pi_{t}^{c}+\omega_{t}^{e} \mathrm{RPIE}_{t}+\omega_{t}^{f} \mathrm{RPIF}_{t}
$$

where

$$
\pi_{t}^{c}=0.41 \pi_{t}^{e}+0.36 \pi_{t-1}^{c}+0.23 \pi_{t-2}^{c}-0.08 \mathrm{SLACK}_{t}+0.57 \mathrm{RPIM}_{t}+\epsilon_{t}
$$

From inspection of Equation (1) and Equation (2), we can observe there are seven (7) adjustable constants all less than unity (shown in bold type) plus an eighth factor on the end of Equation (2). Derived from differential data fitting [1], these constants directly affect the relative contributions of the influence of the economic factors:

$\omega_{t}^{e} \mathrm{RPIE}_{t}$ weighted annual growth rate of energy goods prices.

$\omega_{t}^{f} \mathrm{RPIF}_{t}$ weighted annual growth rate of food and beverage prices.

$\pi_{t}^{e}$ expected long run inflation.

SLACK $_{t}$ level of resource utilization.

RPIM $_{t}$ effect of relative import prices.

$\epsilon_{t}$ white noise term which corrects for "tracking" errors.

Importantly, the successful record of the Federal Reserve in combating inflation and unemployment using policy adjustments has resulted in recent historically low interest rate values. Assuming that the Federal Reserve and its advisors and staff act like any other body or people, we wondered if there was:

1) Any (perhaps hidden) evidence of learning in these trends;

2) A simpler forecasting or fitting equation.

\section{Application of Learning Theory}

Learning theory requires a measure of experience and risk exposure, as going forward individual and system rules and knowledge are corrected for past mistakes and errors. The trial measure we adopted before was the accumulated GDP [2], as being both available and one that is of considerable importance to economic growth and risk exposure. So we thought we would try that again as a starting point, and the GDP is available on-line in trillions of 1991\$. This risk exposure/learning measure also has the considerable advantage that it is possible to correlate and make predictions using simple exponential equations rather than time-series that contain non-linear terms like the numerical calendar year raised to some power, e.g. (2014) power $^{\text {. }}$

We therefore translated all the calendar years into summations of previous successive year GDPs. to give the accumulated GDP for any year, accGDP $(\mathrm{T} \$)=\sum_{t} \mathrm{GDP}_{t}$. Using the starting year, $t=1$ as 1981, as the range adopted in the Yellen [1] paper, the result is shown in Figure 1. The original data are taken from the paper [1], and the solid line is the Federal Reserve trend from the above Equation (1) and Equation (2), and all the 


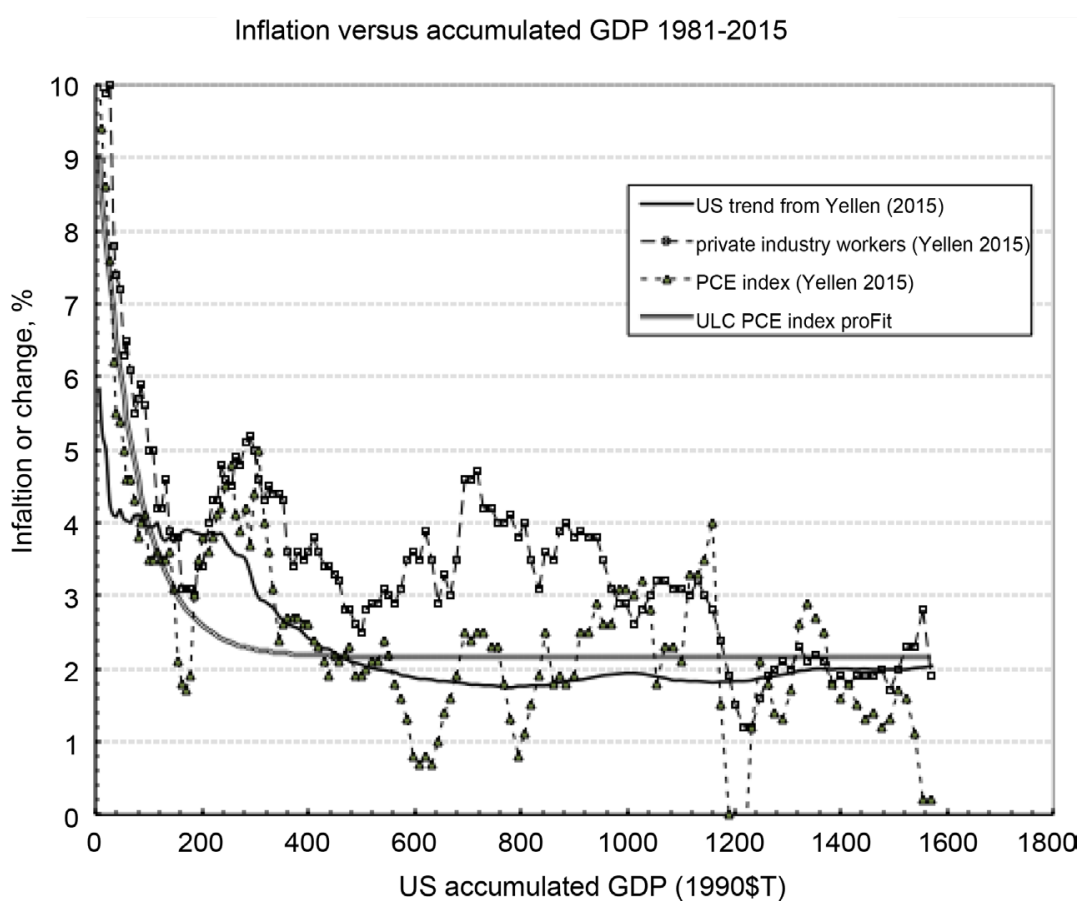

Figure 1. A simple correlation.

tabulated values are given in Appendix A.

Also shown in Figure 1 is the learning trend line for the inflation rate, $\pi_{t}$, as expected from learning theory [3], which fits a myriad of modern system data that exhibit learning from other complex technologies and also covering multiple disciplines (transport, surgical procedures, industrial accidents, near misses, etc.). This exponential form has only three variable parameters, and was fitted to the PCE index data using the commercial software pro Fit version 7, and is given by:

$$
\pi_{t}=2.16+7.6 e^{-\left(\frac{\text { accGDP }}{70}\right)}
$$

We may observe that the e-folding learning scale is about $\$ 70 \mathrm{~T}$, and the underlying expected and actual predicted inflation rate is near $2 \%$, which is the current Federal Reserve target and the future expert expectation ([1], p. 30).

Note the deviation between the Federal Reserve trend line from (1) and (2) is only slightly different from the learning Equation (3). Therefore, there is clear evidence of learning.

\section{Stability and Unemployment}

We can also examine economic stability, particularly in relation to unemployment. For this analysis the data from 1981 onwards were downloaded from the Bureau of Labor Statistics (BLS) website

(http://data.bls.gov/generated files/graphics/latest numbers LNS14000000 19812015

all period M08 data.gif), and converted to quarterly averages to be consistent (see full data Table in Appendix A). 
Inflation trend and Unemployment versus accumulated GDP 1981-2015

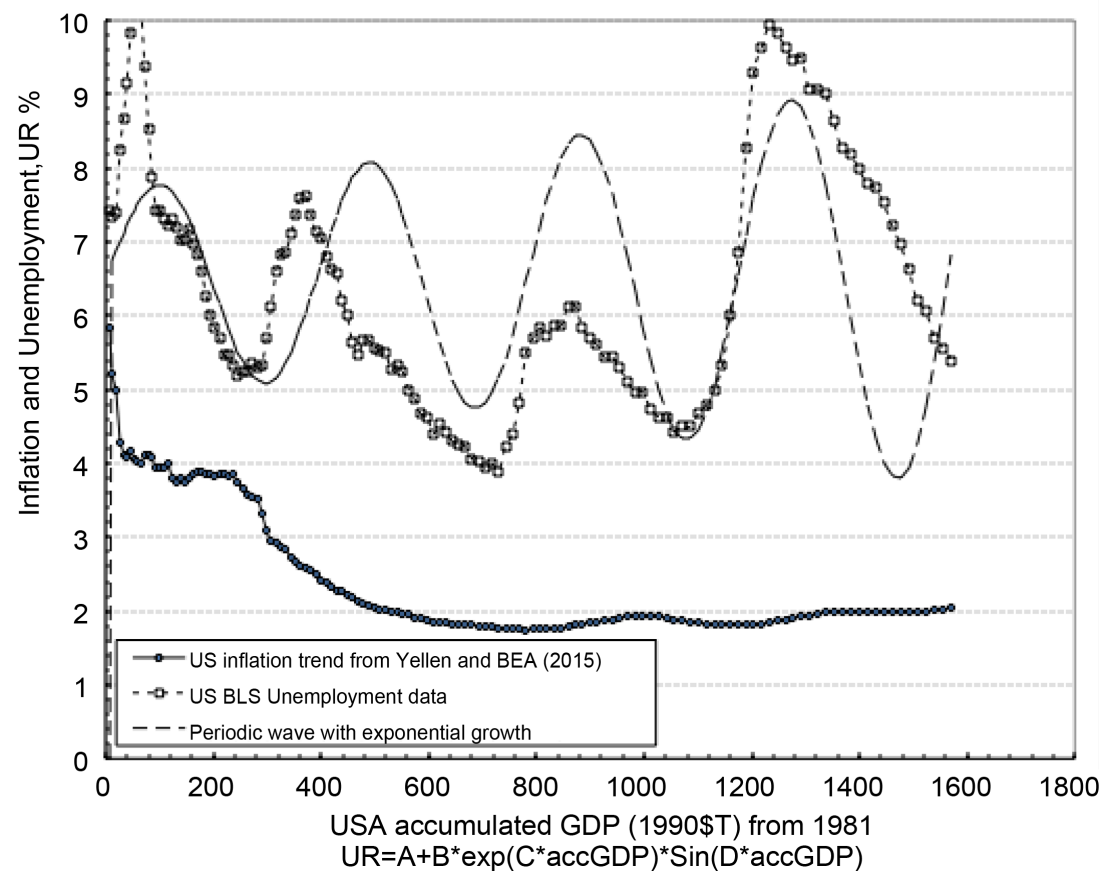

Figure 2. Unemployment and inflation trends.

The result shown in Figure 2 does not show any learning, so clearly is decoupled. The data indicate an underlying quasi-periodic fluctuation with a period, $\phi$, of about $\$ 180 \mathrm{~T}$, and there is also a trend visible of growth in fluctuation amplitude over ten times greater risk/experience exposure. There is an underlying unemployment rate over the interval 1981-2015 of about $6.5 \%$ behind these fluctuations.

The totally empirical equation that was trial fitted to these data is a simple combination of a pure sin wave with an exponential growth amplitude modification. This choice simply reflects the linking of periodic forces and potential instability, as is common in for example in wave dynamics, and is given numerically by:

$$
\mathrm{UR} \approx 6.5+1.2 e^{\left(\frac{\mathrm{accGDP}}{10 \varphi}\right)} \sin \left(\pi \frac{\mathrm{accGDP}}{\phi}\right)
$$

\section{Conclusions and Future Work}

We may conclude that the Federal Reserve has learnt to control inflation rate via an implicit learning process, and has also tempered the fluctuations in unemployment rate, which previously showed evidence of instability.

Yellen [1] also discusses the role of "expectation" in forecasting and economic changes in policies and directions. This behavioral response to rule changes is clearly linked to the learning processes in society and by people, let alone by regulators and financial markets, and is just one aspect of cognitive psychology. The use of learning approaches examined here is a fruitful topic for future research on economic predictions and for interpretive purposes. 


\section{References}

[1] Yellen, J.L. (2015) Inflation Dynamics and Monetary Policy. The Philip Gamble Memorial Lecture, University of Massachusetts, Amherst, Massachusetts, 24 September 2015, 30 p. http://www.federalreserve.gov/newsevents/speech/yellen20150924a1.htm

[2] Duffey, R.B. (2013) The Quantification of Systemic Risk and Stability: New Methods and Measures. In: Haubrich, J.G. and Lo, A.W., Eds., Quantifying Systemic Risk, NBER, University of Chicago Press, Chicago, Chapter 6, 223-264. http://dx.doi.org/10.7208/chicago/9780226921969.003.0008

[3] Duffey R.B. and Saull J.W. (2008) Managing Risk: The Human Element. John Wiley and Sons, Chichester. http://dx.doi.org/10.1002/9780470714461 
Appendix A: Data Tables

\begin{tabular}{|c|c|c|c|c|}
\hline Date & accGDP T\$ & Compensation index & PCE index & Unemployment rate \\
\hline 1981: Q1 & 6.6357 & 10.7 & 10.2 & 7.43 \\
\hline 1981: Q2 & 13.223 & 10.2 & 9.4 & 7.35 \\
\hline 1981: Q3 & 19.8859 & 9.9 & 8.6 & 7.40 \\
\hline 1981: Q4 & 26.471 & 10 & 7.6 & 8.23 \\
\hline 1982: Q1 & 32.946 & 7.8 & 6.2 & 8.67 \\
\hline 1982: Q2 & 39.4562 & 7.4 & 5.5 & 9.15 \\
\hline 1982: Q3 & 45.943 & 7.2 & 5.4 & 9.83 \\
\hline 1982: Q4 & 52.4361 & 6.3 & 5 & 10.67 \\
\hline 1983: Q1 & 59.0143 & 6.5 & 4.6 & 10.37 \\
\hline 1983: Q2 & 65.7426 & 6.1 & 4.6 & 10.13 \\
\hline 1983: Q3 & 72.6026 & 5.5 & 4.3 & 9.37 \\
\hline 1983: Q4 & 79.6041 & 5.7 & 3.8 & 8.53 \\
\hline 1984: Q1 & 86.7447 & 5.9 & 4 & 7.87 \\
\hline 1984: Q2 & 94.0107 & 5.6 & 4.1 & 7.43 \\
\hline 1984: Q3 & 101.3482 & 5 & 3.5 & 7.43 \\
\hline 1984: Q4 & 108.7442 & 5 & 3.5 & 7.30 \\
\hline 1985: Q1 & 116.2137 & 4.2 & 3.6 & 7.23 \\
\hline 1985: Q2 & 123.7516 & 4.2 & 3.5 & 7.30 \\
\hline 1985: Q3 & 131.4068 & 4.6 & 3.5 & 7.20 \\
\hline 1985: Q4 & 139.1194 & 3.9 & 3.6 & 7.03 \\
\hline 1986: Q1 & 146.9035 & 3.8 & 3.1 & 7.03 \\
\hline 1986: Q2 & 154.7233 & 3.8 & 2.1 & 7.17 \\
\hline 1986: Q3 & 162.6219 & 3.1 & 1.8 & 6.97 \\
\hline 1986: Q4 & 170.5614 & 3.1 & 1.7 & 6.83 \\
\hline 1987: Q1 & 178.5564 & 3.1 & 1.9 & 6.60 \\
\hline 1987: Q2 & 186.6411 & 3 & 3 & 6.27 \\
\hline 1987: Q3 & 194.7991 & 3.4 & 3.5 & 6.00 \\
\hline 1987: Q4 & 203.0918 & 3.4 & 3.8 & 5.83 \\
\hline 1988: Q1 & 211.4311 & 4 & 3.6 & 5.70 \\
\hline 1988: Q2 & 219.8806 & 4.3 & 3.8 & 5.47 \\
\hline 1988: Q3 & 228.3789 & 4.3 & 4.1 & 5.47 \\
\hline 1988: Q4 & 236.9898 & 4.8 & 4.2 & 5.33 \\
\hline 1989: Q1 & 245.6875 & 4.6 & 4.5 & 5.20 \\
\hline 1989: Q2 & 254.4536 & 4.5 & 4.8 & 5.23 \\
\hline 1989: Q3 & 263.2851 & 4.9 & 4.1 & 5.23 \\
\hline
\end{tabular}




\section{Continued}

\begin{tabular}{|c|c|c|c|c|}
\hline 1989: Q4 & 272.1353 & 4.8 & 3.9 & 5.37 \\
\hline 1990: Q1 & 281.0824 & 5.1 & 4.2 & 5.30 \\
\hline 1990: Q2 & 290.0641 & 5.2 & 3.7 & 5.33 \\
\hline 1990: Q3 & 299.048 & 5 & 4.4 & 5.70 \\
\hline 1990: Q4 & 307.9554 & 4.6 & 5 & 6.13 \\
\hline 1991: Q1 & 316.821 & 4.3 & 4 & 6.60 \\
\hline 1991: Q2 & 325.7554 & 4.5 & 3.6 & 6.83 \\
\hline 1991: Q3 & 334.7327 & 4.4 & 3.1 & 6.87 \\
\hline 1991: Q4 & 343.7491 & 4.4 & 2.4 & 7.10 \\
\hline 1992: Q1 & 352.8721 & 4.3 & 2.6 & 7.37 \\
\hline 1992: Q2 & 362.0956 & 3.6 & 2.7 & 7.60 \\
\hline 1992: Q3 & 371.4088 & 3.4 & 2.7 & 7.63 \\
\hline 1992: Q4 & 380.8153 & 3.6 & 2.7 & 7.37 \\
\hline 1993: Q1 & 390.2394 & 3.5 & 2.6 & 7.13 \\
\hline 1993: Q2 & 399.7195 & 3.6 & 2.6 & 7.07 \\
\hline 1993: Q3 & 409.2458 & 3.8 & 2.4 & 6.80 \\
\hline 1993: Q4 & 418.8993 & 3.6 & 2.3 & 6.63 \\
\hline 1994: Q1 & 428.6475 & 3.4 & 2.1 & 6.57 \\
\hline 1994: Q2 & 438.5289 & 3.4 & 1.9 & 6.20 \\
\hline 1994: Q3 & 448.4686 & 3.3 & 2.2 & 6.00 \\
\hline 1994: Q4 & 458.5211 & 3.2 & 2.1 & 5.63 \\
\hline 1995: Q1 & 468.608 & 2.8 & 2.2 & 5.47 \\
\hline 1995: Q2 & 478.7301 & 2.8 & 2.3 & 5.67 \\
\hline 1995: Q3 & 488.9389 & 2.6 & 1.9 & 5.67 \\
\hline 1995: Q4 & 499.2201 & 2.5 & 1.9 & 5.57 \\
\hline 1996: Q1 & 509.5688 & 2.8 & 2 & 5.53 \\
\hline 1996: Q2 & 520.0982 & 2.9 & 2.1 & 5.50 \\
\hline 1996: Q3 & 530.725 & 2.9 & 2.1 & 5.27 \\
\hline 1996: Q4 & 541.4641 & 3.1 & 2.4 & 5.33 \\
\hline 1997: Q1 & 552.285 & 3 & 2.2 & 5.23 \\
\hline 1997: Q2 & 563.2692 & 2.9 & 1.8 & 5.00 \\
\hline 1997: Q3 & 574.3932 & 3.1 & 1.6 & 4.87 \\
\hline 1997: Q4 & 585.6035 & 3.5 & 1.3 & 4.67 \\
\hline 1998: Q1 & 596.9247 & 3.6 & 0.8 & 4.63 \\
\hline 1998: Q2 & 608.3557 & 3.5 & 0.7 & 4.40 \\
\hline 1998: Q3 & 619.9363 & 3.9 & 0.8 & 4.53 \\
\hline 1998: Q4 & 631.707 & 3.5 & 0.7 & 4.43 \\
\hline
\end{tabular}


Continued

\begin{tabular}{|c|c|c|c|c|}
\hline 1999: Q1 & 643.5717 & 2.9 & 1 & 4.30 \\
\hline 1999: Q2 & 655.5342 & 3.3 & 1.4 & 4.27 \\
\hline 1999: Q3 & 667.6473 & 3 & 1.6 & 4.23 \\
\hline 1999: Q4 & 679.9706 & 3.5 & 1.9 & 4.07 \\
\hline 2000: Q1 & 692.3297 & 4.6 & 2.5 & 4.03 \\
\hline 2000: Q2 & 704.9222 & 4.6 & 2.4 & 3.93 \\
\hline 2000: Q3 & 717.5299 & 4.7 & 2.5 & 4.00 \\
\hline 2000: Q4 & 730.2092 & 4.2 & 2.5 & 3.90 \\
\hline 2001: Q1 & 742.8525 & 4.2 & 2.3 & 4.23 \\
\hline 2001: Q2 & 755.5628 & 4 & 2.3 & 4.40 \\
\hline 2001: Q3 & 768.2329 & 4 & 1.8 & 4.83 \\
\hline 2001: Q4 & 780.9382 & 4.1 & 1.3 & 5.50 \\
\hline 2002: Q1 & 793.7605 & 3.8 & 0.8 & 5.70 \\
\hline 2002: Q2 & 806.6535 & 4 & 1.1 & 5.83 \\
\hline 2002: Q3 & 819.6093 & 3.5 & 1.5 & 5.73 \\
\hline 2002: Q4 & 832.5733 & 3.1 & 1.9 & 5.87 \\
\hline 2003: Q1 & 845.6045 & 3.6 & 2.5 & 5.87 \\
\hline 2003: Q2 & 858.7566 & 3.5 & 1.8 & 6.13 \\
\hline 2003: Q3 & 872.129 & 3.9 & 1.9 & 6.13 \\
\hline 2003: Q4 & 885.6577 & 4 & 1.8 & 5.83 \\
\hline 2004: Q1 & 899.2642 & 3.8 & 1.9 & 5.70 \\
\hline 2004: Q2 & 912.9704 & 3.9 & 2.5 & 5.60 \\
\hline 2004: Q3 & 926.8012 & 3.8 & 2.5 & 5.43 \\
\hline 2004: Q4 & 940.7516 & 3.8 & 2.9 & 5.43 \\
\hline 2005: Q1 & 954.8507 & 3.5 & 2.6 & 5.30 \\
\hline 2005: Q2 & 969.0234 & 3.1 & 2.6 & 5.10 \\
\hline 2005: Q3 & 983.3152 & 2.9 & 3.1 & 4.97 \\
\hline 2005: Q4 & 997.6886 & 2.9 & 3.1 & 4.97 \\
\hline 2006: Q1 & 1012.2347 & 2.6 & 3 & 4.73 \\
\hline 2006: Q2 & 1026.8243 & 2.8 & 3.2 & 4.63 \\
\hline 2006: Q3 & 1041.4269 & 3 & 2.8 & 4.63 \\
\hline 2006: Q4 & 1056.1438 & 3.2 & 1.8 & 4.43 \\
\hline 2007: Q1 & 1070.8698 & 3.2 & 2.3 & 4.50 \\
\hline 2007: Q2 & 1085.7085 & 3.1 & 2.3 & 4.50 \\
\hline 2007: Q3 & 1100.647 & 3.1 & 2.1 & 4.67 \\
\hline 2007: Q4 & 1115.6388 & 3 & 3.3 & 4.80 \\
\hline
\end{tabular}




\section{Continued}

\begin{tabular}{|c|c|c|c|c|}
\hline 2008: Q1 & 1130.5283 & 3.2 & 3.3 & 5.00 \\
\hline 2008: Q2 & 1145.4917 & 3 & 3.5 & 5.33 \\
\hline 2008: Q3 & 1160.3833 & 2.8 & 4 & 6.00 \\
\hline 2008: Q4 & 1174.9603 & 2.4 & 1.5 & 6.87 \\
\hline 2009: Q1 & 1189.3353 & 1.9 & 0 & 8.27 \\
\hline 2009: Q2 & 1203.6909 & 1.5 & -0.6 & 9.30 \\
\hline 2009: Q3 & 1218.0934 & 1.2 & -0.9 & 9.63 \\
\hline 2009: Q4 & 1232.6353 & 1.2 & 1.2 & 9.93 \\
\hline 2010: Q1 & 1247.2401 & 1.6 & 2.1 & 9.83 \\
\hline 2010: Q2 & 1261.986 & 1.9 & 1.8 & 9.63 \\
\hline 2010: Q3 & 1276.8315 & 2 & 1.4 & 9.47 \\
\hline 2010: Q4 & 1291.7705 & 2.1 & 1.3 & 9.50 \\
\hline 2011: Q1 & 1306.6518 & 2 & 1.7 & 9.07 \\
\hline 2011: Q2 & 1321.6414 & 2.3 & 2.6 & 9.07 \\
\hline 2011: Q3 & 1336.6625 & 2.1 & 2.9 & 9.00 \\
\hline 2011: Q4 & 1351.8528 & 2.2 & 2.7 & 8.63 \\
\hline 2012: Q1 & 1367.1438 & 2.1 & 2.5 & 8.27 \\
\hline 2012: Q2 & 1382.5062 & 1.8 & 1.8 & 8.20 \\
\hline 2012: Q3 & 1397.887 & 1.9 & 1.6 & 8.00 \\
\hline 2012: Q4 & 1413.2713 & 1.8 & 1.8 & 7.80 \\
\hline 2013: Q1 & 1428.7285 & 1.9 & 1.5 & 7.73 \\
\hline 2013: Q2 & 1444.2287 & 1.9 & 1.3 & 7.53 \\
\hline 2013: Q3 & 1459.8431 & 1.9 & 1.4 & 7.23 \\
\hline 2013: Q4 & 1475.6046 & 2 & 1.2 & 6.97 \\
\hline 2014: Q1 & 1491.3295 & 1.7 & 1.3 & 6.63 \\
\hline 2014: Q2 & 1507.231 & 2 & 1.7 & 6.20 \\
\hline 2014: Q3 & 1523.2998 & 2.3 & 1.6 & 6.07 \\
\hline 2014: Q4 & 1539.4512 & 2.3 & 1.1 & 5.70 \\
\hline 2015: Q1 & 1555.6285 & 2.8 & 0.2 & 5.57 \\
\hline 2015: Q2 & 1571.9621 & 1.9 & 0.2 & 5.40 \\
\hline
\end{tabular}


Submit or recommend next manuscript to SCIRP and we will provide best service for you:

Accepting pre-submission inquiries through Email, Facebook, LinkedIn, Twitter, etc. A wide selection of journals (inclusive of 9 subjects, more than 200 journals)

Providing 24-hour high-quality service

User-friendly online submission system

Fair and swift peer-review system

Efficient typesetting and proofreading procedure

Display of the result of downloads and visits, as well as the number of cited articles

Maximum dissemination of your research work

Submit your manuscript at: http://papersubmission.scirp.org/ 